\title{
COLEOPTERA FAUNA IN FOREST ECOSYSTEM OF SHIVALIK HILLS REGION OF INDIA - A MINI REVIEW
}

\author{
*Sanjay Paunikar \\ Zoological Survey of India, Northern Regional Centre, 218, Kaulagarh Road, Dehradun-248195, Uttarakhand, India
}

Article History: Received 09 ${ }^{\text {th }}$ September 2021; Accepted 04 $4^{\text {th }}$ October 2021; Published $31^{\text {st }}$ October 2021

\begin{abstract}
A review is given on documentation of important and major insect order Coleoptera in the forest ecosystem of Shivalik Hill regions of India. Shivalik Hills is situated in the north Indian region to the foothills of North-West Himalaya. Its position makes its unique biogeographic location, diversified climatic conditions, and enormous eco-diversity and geodiversity of flora and fauna. Several renowned workers contributed and documented the number of species of Coleoptera of the Shivalik Hills region of India. After reviewing the literature on Coleoptera fauna in the Shivalik Hills areas indicates some fragmentary work on different aspects of Coleoptera such as taxonomic, bioecology, species diversity, seasonal abundance, distribution and pest status. Though, it was found that some documents were published but, it is needed to explore more coleopteran fauna and prepare to consolidate documents from the forest ecosystem of Shivalik Hills and detailed study on taxonomy, bioecology, species diversity, abundance and distribution in forest ecosystem due to current changing climatic condition.
\end{abstract}

Keywords: Entomofauna, Shivalik Hills, Coleoptera fauna, Beetles, Insect diversity, Forest ecosystem.

\section{INTRODUCTION}

India is one of the world's most biodiverse regions, with a total land area of about $3,287,263 \mathrm{~km}^{2}$, covering a variety of ecosystems ranging from deserts to high mountains and tropical to temperate forests. Insects are the most abundant of all life forms on earth. India with about $2 \%$ of the global land area is among the top 12 mega biodiversity nations in the world. Forests in India are highly diverse and encompass several forest types such as evergreen tropical rain forests, dry alpine scrub types, semi evergreen rain forests, deciduous monsoon forests, subtropical pine forests, and temperate montane forests (Lal, 1989). In total, 16 major forest types occur (based on temperature and moisture conditions), which in turn are subdivided into 221 minor types (based on location-specific climatic and edaphic conditions) (Champion \& Seth, 1968). Forest is one of the most important terrestrial ecosystems (FAO,
2010) and it has been regarded as one of the most species rich habitats, especially for arthropods (Adis et al., 1997; Stork, 1988).

The Shivalik landscape $\left(29^{\circ} 57^{\prime}\right.$ to $31^{\circ} 20^{\prime} \mathrm{N}$ and $77^{\circ} 35^{\prime}$ to $\left.79^{\circ} 20^{\prime} \mathrm{E}\right)$ is the youngest mountain range of the Himalayas and is aligned parallel to the Lesser Himalayas. The area has been categorized as Indo-Gangetic plains and is biogeographically significant due to the presence of both Indo-Malayan and Palaearctic elements (Mani, 1968; Wadia, 1975). The Shivalik trail is 10 million year old and very rich in fossils. It is characterized by fragile land formation, sub-tropical climate, varied topography and rich alluvial soils. The entire Shivalik belt covers an area of approximately $40,000 \mathrm{~km}^{2}$, of which only $3000 \mathrm{~km}^{2}$ is listed as wildlife protected area network. The Shivalik spans six Indian states namely, Jammu and Kashmir, Himachal Pradesh, Punjab, Haryana, Uttarakhand and Uttar Pradesh. The forest ecosystem of the abovementioned 
states is at present in a highly degraded form, with only little remaining of the primary forest those once covered large areas Shivalik Hills symbolize one of the most fragile ecosystems and have been identified as one of the eight most degraded rains fed sagro systems of the country. Shivalik ranges between Indus and Kosi River is considered as the Northwest Shivaliks. The Shivaliks or the sub-Himalayan tracts, categorized under Indo-Gangetic plains has special significance in India's biogeography due to intermingling of taxa from the Indo-malayan and Palaearctic regions (Agrawal et al., 2002; Jerath \& Chadha, 2006; Johnsingh et al., 2004; Rawat \& Mukherjee, 2005).

The major vegetation types from west to east along the increasing rainfall gradient are Deodar scrub, Sub-tropical Pine Forests, Dry Shivalisk Sal and Teak Forest and Moist Mixed Deciduous Forest (Champion \& Seth, 1968; Jerath $\&$ Chadha, 2006). The other forest tree species found in the Shivalik Hills are Acacia catechu, Acacia modesta, Acacia nilotica, Adina cordifolia, Albizzia procera, Ailanthus excelsa, Anogeissus latifolia, Azadirachta indica, Bamboos sp.,Bombax ceiba, Butea monosperma, Cadrelatonna, Dalbergia sissoo, Eucalyptus spp.,Ficus glomerata, Garuga pinnata, Kydiacalycina, Lagerstromia parviflora, Lanneacoro mandelica Moringa sp., Pinus roxburghii, Shorearobusta, Stereospermumchelonoides, Tectona grandis, Terminalia tomentosa, Terminalia ballerica, Trewianudi flora and many more (Bhardwaj et al., 2017).The Shivalik Hills areas is recogsnied unique and rich floral and faunal diversity.

\section{COLEOPTERA FAUNA IN INDIA}

Pajni, (1990) published Coleoptera Fauna of India and adjacent countries. These contribute to a diversified beetle fauna and India holds about 5 per cent of all known species of the world, i.e., about 15,500 species belonging to 104 families under 3 suborders. Ramakrishna, (2007) on the status of Indian Coleoptera n include about 17,431 species under 113 species. However, current documentation and data compilation by the Zoological Survey of India (ZSI), on the known beetle diversity of India, roughly resulted in the list of 22,299 species, so far from the country (Chandra et al., 2018). Zoological Survey of India (ZSI) a premier organization working on zoological research and studies to promote the survey, exploration, taxonomy and research of the faunal diversity of the country, states, union territories, national parks, wildlife sanctuaries, conservation areas, protected areas and many other areas of India and published books, technical monographs, state fauna series, records, ecosystem series, bulletins, special publications, handbooks and pictorial guides, status survey of endangered species, memories, occasional papers and research papers in regular intervals. There are several renowned workers also published their work on British Fauna of India on Coleoptera time to time. The major contribution given by (Andrews, 1935; Andrews, 1929; Arrow, 1949; Arrow, 1910, 1925, 1931, 1943; Beeson, 1941; Cameron, 1930, 1939; Fowler, 1912; Gahan, 1906; Keffer et al., 1908; Lefroy \& Howlett, 1909; Marshall,
1916; S Maulik, 1919; Samarendra Maulik, 1926, 1936; Nair, 2007; Stebbing, 1899; Vazirani, 1977; Vazirani, 1984; Verma et al., 2017).

Recently, Trigunayat \& Sharma, (2017) reviewed the diversity and ecology of Coleoptera in India and much not much given information on Coleoptera taxonomy diversity, species status and distribution. There are some workers reviewed on Coleoptera fauna on their taxonomy, diversity, species status and distribution in varied ecosystem in India (Kazmi \& Ramamurthy, 2004; Mahendiran \& Ramamurthy, 2013; Thakare \& Zade, 2012). But, very few information are have been published on the fauna of Coleoptera, their taxonomy, bioecology, distribution, species diversity and seasonal abundance and pest status of Shivalik Hills areas of India. It is required to explore and prepare consolidate document on Coleoptera fauna and other enotmofauna of forest ecosystem of Shivalika Hills region of India, which is one of the hotspot areas due to their unique position in foothills of Himalaya.

\section{ROLE OF COLEOPTERA IN FOREST ECOSYSTEM}

Beetles comprise the largest insect order Coleoptera (the name derived from two Greek words, meaning a sheath, and a wing). The beetle's exoskeleton is made up of numerous plates called sclerites, separated by thin sutures. This design creates the armoured defenses of the beetle while maintaining flexibility. One of the most distinctive features of Coleoptera is the structure of the wings. Beetles are exceedingly variable both ecologically and biologically. The majorities of beetle are terrestrial herbivores; many are pests and predatory, frequently with highly specialized host ranges or life cycles. Their role in the functioning of forest ecosystem, especially the terrestrial ones is immense. More than one out of every four named species of animal is a beetle. Out of about $8,00,000$ described species of insects Coleoptera alone shares about 3, 50,000 species belonging to 177 families under 4 suborders, Myxophaga, Adephaga and Polyphaga. The several families of order Coleoptera such as, Scarabaeidea, Melolonthidea, Curculionidae, Cerambycidae, Bruchidae, Tenebrionidae, Chrysomelidae, Bruprestidae, Elateridae, Cantharidae, Bostrychidae, Coccinelilidae, Hydrophilidae, Dytiscidae, Carabidae, Cicindelidae are economic importance and play significance role in the different ecosystem.

Beetles are in nearly every food chain. Many larger animals' birds, bats, amphibians, and fish eat beetles and their larvae/grubs before they in turn are eaten by predators. Beetles are plays significant role in forest ecosystem as a pollinators, decomposer, predators and pests. Some coleopteran families are beneficial for forest health as well as some families is very harmful for the health of forest. Waste-eating beetles like Carabidae family live in forest floor debris and unlock nutrients for use by the ecosystem that would otherwise stagnate in dung, dead plants, and carrion. Monitoring the diversity and conservation status of beetles is important because they play a critical role in recycling the organic matter in nature. Beetles influence 
the ecosystem in many ways. They help cycle nutrients in the soil when they bury the dung or carrion. By removing the dung, they prevent populations of parasitic flies from breeding in the fresh faeces of mammals. The dung of the fruit-eating vertebrates may have seeds so the rollers act as dispersal agents, taking the seeds to places far away, providing it with nutrients from the dung for germination, and so helping with forest regeneration. By feeding on crop-threatening pests, predatory insects (Coccinelidea, Elateridae) perform the role of pesticides without chemicals. This cuts pest control costs and increases yields, saving forestry and agricultural industries billions of dollars every year while reducing toxic pesticide residue on crops.

Some families of beetles (Hoploceram byxspinicornis, Acanthophorus serraticornis, Aeolesthesholosericea, Anamola spp., Apriona spp., Holotrichia spp. Celosternas cabrator, Chlorophorus strobilicola, Cryptorhynchus rufescens, Oryctes rhinoceros, Stromatium barbatum, Plocaederus obesus, Sitophilus rugicollis, Batocera spp., Xystocera globosa, and others important species) and weevils (Caryedon spp., Myllocerus spp. and other) are severe insect pests of forestry, agricultural and horticultural crops as well as store grains and seeds in India and abroad, cause heavy losses of the crops annually (Beeson, 1941; Browne, 1968; Dhaliwal et al., 2010; Kulkarni \& Joshi, 1998; Roonwal, 1978; Sambaraju et al., 2016; Singh, 1988; Tewari, 1992). Some of them are predators on the harmful insect pests and balance the ecosystem. Scarabaeidae family is the largest family of insect which includes more than 30000 species in the world. Dung beetles, that family of Scarabaeide have been effectively used to decrease the population of parasitic worms and pestilent flies that breed in cattle. Ground beetles (Carabidae) are common predators of many diverse insects and other arthropods, including wireworms, fly eggs, caterpillars and other (Banerjee, 2014). The leaf stem, seeds, root and bark beetles (Cerambycidae, Chrysomelidae, Bruchidae, Brupesticidae, Bostrychidae, Curculionidae, Scarabaeidea, Scolytidea, Platypodidea and Tenebrionidae) being phytophagous, the group includes various established and potential forestry and agricultural pests in India. Some of the families of Coleoptera like Gyrinidae, Haliplidae, Noteridae, Amphizoidae, Dytiscidae and Hydroscaphidae are aquatic in all life stages. The adult water beetles from family Hydroscaphidae, Hydrophilidae, Lutrochidae, Dyropidae, Elmidae, Eulichadidae, Heteroceridae, Limnichidae, Psephenidae, Ptilodactylidae and Sphaeriusidae are not aquatic. Water beetles are very integral parts of the biotic component of any water bodies or wetlands. They are indicator of ecological diversity and habitat characteristics of forest ecosystem.

\section{COLEOPTERA FAUNA IN SHIVALIK HILLS}

Perusal of literature revealed that several workers contributed and documented their work in very few insect orders of Shivalik Hills region of India since $18^{\text {th }}$ Century. Zoological Survey of India worked out and published several books on faunal diversity including Coleoptera fauna of Corbett National park, Rajaji National Park, Fauna of Asan Wetland, Faunal Diversity of Western Doon Shivalik and Fauna of Uttarakhand, which are the major parts of Shivalik Hills areas (Editor-Director, 1995, 2003, $2007,2008,2010)$. Some workers studied on the taxonomy, diversity, distribution and relative abundance of different orders/species/subspecies of entomofauna including Coleoptera from different parts of Shivalik Hills region. The significance contributions had been given in Coleoptera $\mathrm{n}$ fauna from Shivalik Hills areas of India by (Ahmad, 2000; Manoj et al., 2014; Manoj Kumar Arya \& Tamta, 2016; Vinay Bhargav et al., 2009; Bind, 1995; Chakraborty et al., 2010; Kailash Chandra et al., 2012; Chandra \& Ramesh, 2013; Chatterjee \& Thapa, 1970; Chatterjee \& Biswas, 2010; Joshi \& Sharma, 2008; Mukhopadhyay et al., 2010; Omkar \& Pervez, 1999, 2002; Pajni \& Bedi, 1973; Pajni \& Singal, 1974; Pajni \& Singh, 1982; Pathania, 2015; Poorani, 2002; Roonwal, 1952; Uniyal \& Bhargav, 2007).

Roonwal (1952) studied of a recent epidemic of the sal (Shorearobusta) heartwood borer, Hoplocerambyx spinicornis Newm. (Coleoptera: Cerambycidae) in Nahan Forest Division, Himachal Pradesh. (Chatterjee \& Thapa, 1970) noted the epidemic on sal heartwood borer, Hoplocerambyx spinicornis New. In the Sal forest, Dehra Dun. (Pajni \& Singal, 1974) identified Corigetus chandigarhensis sp. nov., a new Curculioned (Coleoptera: Curculionedae: Otierhynchinae: Ptochini: Cyphicerina) from Chandigarh. The complete description of the species has been recorded giving the intra-specific variation in the colouration of the scales. Pajni \& Singh (1982) reported family Coccinellidae of Chandigarh and its surrounding area. The history of the genus Corigetus has been discussed to highlight its pending splitting into several genera. Thapa \& Pratap (1990) found the two bark borer, Melano philoignicola and another the sap wood borer, Sphenoptera aterrima which badly damaged the bark and formed a girdle around the tree trunks resulting in slow death or trees in Nahan Forest Division, Himachal Pradesh. Omkar \& Pervez, (1999) have reported 6 species of coccinellids from Lucknow region of central U.P., to this added 17 new species, while (Omkar \& Pervez, 1999, 2002) further added 17 more species from the same region.

Ranjeet et al., (2001) recorded four species of beetles, Sphenoptera aterrima (Bruprestidae), Cryptorhynchus rufescens (Curculionidae), Platypus biformis (Curculionidae: Platypodidae) and Polygraphus longifolia (Curculionidae: Scolytinae) caused heavy mortality of chir pines (Pinus roxburgii) in India which occur in the tropical mixed forest at Morni Hills, Haryana patches under Shiwalik Hill ranges. Poorani, (2002) has listed 400 species of Coccinellids from Indian subregion, which includes the erstwhile state of Uttar Pradesh including the Uttarakhand. Joshi \& Sharma, (2008) identified to 31 species, of which 19 species recorded for the first time from within the Haridwar. These 19 newly recorded species belonged to 16 genera of four tribes and three subfamilies. The following 16 species belonged to the sub family Coccinellinae and tribe Coccinellini: Adalia decempunctata (Linnaeus), Anegleis cardoni (Weise), Cheilomenes sexmaculatarufa 
fasciata (Fabricius), Coelophora 9-maculata (Mulsant), Coelophora ramosa (Olivier), Harmonia dimidiate (Fabricius), Hippodamia variegate (Goeze), Hippodamia sp., Illeiscincta (Fabricius), Megalocaria dilatata (Fabricius), Micraspis discolor (Fabricius), Micraspis vincta (Fabricius), Phrynocariasp., Propylea dissecta (Mulsant), Halyzia sanscrita (Mulsant) and Psylloborab isoctonata (Mulsant). Two species occurred in the subfamily Chilocorinae and tribe Chilocirini: Brumoides suturalis (Fabricius) and Chilocorus nigrita (Fabricius) and only one species Rodolia sexnotata (Mulsant) represented the Noviini tribe of the subfamily Coccidulinae. Uniyal et al. (2007) studied the tiger beetles in Shivalik hills of Himachal Pradesh. Uniyal \& Bhargav, (2007) conducted ecological study of tiger beetles Cicindelidae as indicator for Biodiversity monitoring in Shivalik Himalaya.

Bhardwaj et al. (2008) investigated the communal roosting of tiger beetles (Cicindelidae: Coleoptera) in the Shivalik hills, Himachal Pradesh, India. Bhargav \& Uniyal, (2008) documented twelve species of Tiger beetles in five different habitat types in Chilla Wildlife Sanctuary of Rajaji National Park, Uttarakhand. Riverine habitat was found to be appropriate habitat for eight tiger beetle species. Vinay Bhargav et al. (2009) described the distribution pattern of tiger beetles in Shorea robusta dominated forest ecosystems at landscape level of north western Shivalik Himalaya in environmental space and to evaluate the nature of microhabitat association amongst recorded species of tiger beetles. Twenty-five species of tiger beetles belonging to ten genera were recorded from six protected areas in the tropical dry deciduous Shivalik region with an altitudinal gradient of 350-1,400 m above mean sea level in north western India. Chandra et al. (2018) while studying the scarab beetle fauna of Uttarakhand reported 44 species belonging to 16 genera and 3 subfamilies, which 6 species is new record from the state.

Mukhopadhyay \& Ghosh (2010) studied 10 spp. under 2 genera of the family Gyrinidae and $30 \mathrm{spp}$. The under 16 genera are belonging to the 5 subfamilies viz., Noterinae, Laccophilinae, Hydroporinae, Colymbetinae and Dytiscinae. Of which the species, Orectochilus (s. str.) murinus is recorded for the first time from Uttarakhand. And 15 species under 10 genera belonging to the subfamilies viz., Noterinae, Laccophilinae, and Colymbetinae of Dytiscidae are recorded for the first time from Uttarakhand and the species, L. (s. str.) basalis is recorded for the first time from India. (Chatterjee \& Biswas, 2010) reported 147 examples comprising 44 species Scarabaeidae under 16 genera belonging to 3 subfamilies are included in this paper of which 6 species are new record from the state. Chakraborty (2010) recorded 914 examples of Coccinellidae beetles belonging to 39 species under 23 genera and 5 subfamilies. Out of 39 species 8 species were recorded earlier from Kumaon Hills and other places under V.P. Two species are recorded first time from India as well as the state. A new species, $H$. chamolika has been described. Genus Egius has been recorded for the first time from India as well as the state. A new combination has been reported Epilachnaexpansa $=$ Afissaexpansa. Chakraborty (2010) reported 12 species under 9 genera and 2 subfamilies. All these 12 species are recorded for the first time from the state.

Mukhopadhyay et al. (2010) reported 52 species under 19 genera belonging to 5 subfamilies viz, Hydraeninae, Limnebiinae, Epimetopinae, Sphaeridiinae and Hydrophilinae. Of which 19 species fewer than 11 Genera of the families like Sphaeridiinae and Hydrophilinae are recorded for the first time from this state. Mukhopadhyay et al. (2010) described 110 species under 23 genera belonging to the subfamily Paederinae: Staphylinidae. Of which three species are viz., Paederus sharpi, P. coxalis and Cryptobiumcey lanense are recorded for the first time from India and 16 species under 5 genera are recorded for the first time from the state. Kailash Chandra et al., (2012) reported comprising 11 species belonging to 11 genera, 5 subfamilies and 2 families of superfamily Scarabaeoidea from Govind Wild Life Sanctuary. These species are recorded for the first time from the sanctuary while three species viz., Anomala cantor, Mimelapas serinii and Oryctes nasicornis are new record to the fauna of Uttarakhand. The paper also includes an updated checklist of the scarab beetles of Uttarakhand comprising 167 species belonging to 52 genera, 21 tribes, 9 subfamilies and 3 families of super family Scarabaeoidea. Manoj et al. (2014) have recorded 17 species of beetles belonging to 6 families from Shyampur forest range in Shivalik foot hills of Haridwar, India.

Pathania (2015) reported 56 species of Scarabaeid beetles belonging to 20 genera and 4 subfamilies from different landscapes of Himachal Pradesh, India. Manoj Kumar Arya \& Tamta (2016) recorded 23 species, 18 genera and 6 families' beetles from Binsar Wildlife Sanctuary in district Almora, Uttarakhand, India. On the basis of total number of species Scarabaeidae was the most dominant family with 8 species followed by Chrysomelidae (5 species), Coccinellidae (2 species), Meloidae (2 species), Lagriidae and Tenebrionidae (1 species each), respectively. On the basis of total number of individuals Coccinella septumpunctata Linnaeus was the most abundant species and constituted $16.62 \%$ of the total beetles followed by Anomalasp. (13.21\%) and Alticahi mensis Shukla (12.40\%). Singh et al. (2017) reported 16 species of scarab beetles belonging to 9 genera, 2 subfamilies (Scarabaeinae and Aphodiinae) and 1 family (Scarabaeidae) of superfamily Scarabaeoidea of Coleoptera. All the 16 species were reported for the first time from the Sahaspur, Dehradun, Uttarakhand of which Onthopha gusmopsus, Onthopha guscervus Aphodiusrufipes and Aphodiu serraticus are new record to the Scarab fauna of Uttarakhand. Singh et al. (2018) assessed the Coleoptera $\mathrm{n}$ fauna of forest ecosystem of Siswan, Punjab which is located in the Majri Tehsil of Mohali district of Punjab in the western Shivalik Hill range. A total of 43 species belonging to 32 genera and 12 families were identified. Out of these 12 families, family Scarabaeidae (dung beetles) was dominant (with 20 species), followed by family Chrysomelidae (leaf beetles, 4 species) and family 
Coccinellidae (ladybird beetles, 3 species) and family Meloidae (Blister beetles, 3 species. All the taxa are reported from the area for the first time from this forest ecosystem.

Recently, Mishra \& Yousuf, (2019) recorded coccinellid beetles from forest ecosystem of Shiwalik Hill areas of Uttarakhand. They identified fifteen species of coccinellid beetles as Aiolocari ahexaspilota, Anegleis

cardoni, Brumoi dessuturalis, Coccinella septempunctata, C. transversalis, Harmonia dimidiata, Henosepila chnavigintiocto punctata, Hippodamia variegata, Illeisconfusa, Menochilus sexmaculatus, Micraspi sallardi, Micraspis univittata, Oenopia sexareata, Platynaspidius saundersi and Propylea dissecta. H. vigintioctopunctata is phytophagous while I. confuse is mycophagous; all other species are predatory feeding on mealy bugs and aphids occurring on forest tree species. Out of all identified species, four species A. hexaspilota, I. confusa, $O$. sexareata and $P$. saundersi have been recorded for the first time from Uttarakhand. Ahmad \& Moina, (2019) recorded 18 species from five different zoogeographical habitats in Uttarakhand, North India. They described species belonging to three sub-families (Chilocorinae Scymninae Coccinellinae), three tribes (Platynaspidini Scymnini Coccinellinae) and thirteen genera. Seven-spotted ladybird, Coccinella septempunctata was highly abundant $(32.13 \%$ of total frequency), followed by Menochilus sexmaculatus (23.69\%). Platynaspis saundersi was the least abundant ladybird species. Shannon Wiener's index was the highest (2.1012) for Chamoli region exhibiting it as most species diverse habitat, which is the reason for the high pooled SW index of 2.0349 from Uttarakhand.

\section{WHY NEED TO STUDY?}

Beetles play significant role in forest ecosystem as preys, predators, pollinators, and decomposer and as pests. They are beneficial and harmful for the forest ecosystem. As review provide information about documentation of major order Coleoptera from forest ecosystem of Shivalik Hills region of India. The documented data is also in point of view rich diversity of Coleoptera from Shivalik Hills. Due anthropogenic pressure, degraded forest habitat, pollution, climate change, invasive species the entomofaunal diversity is decreasing. So there is needed documentation of insect biodiversity for conservation and planning to protected areas, national parks, wild life sanctuaries for justification and design and development of management plans. The data study on the taxonomy and systematic, bioecology, distribution, species abundance, pest status, predatory potential of Coleoptera will be very useful to field entomologists, scientists, researchers and students and for quick and accurate field recognition of the diversity of entomofauna of Shivalik Hills of India.

The literatures indicated that the fragmentary work on different aspects of Coleoptera such as bioecology, diversity, taxonomic, distribution, species abundance and pest status. Current status of commonly available rare, endangered and threatened species of Coleoptera is not known. So, it is needed to explore more diversity of insect fauna including Coleoptera and to prepare comprehensive documents on different aspects of taxonomic, bioecology, distribution, species richness and pest status due to current changing climatic condition.

\section{DISCUSSION}

The above findings in this review highlight a number of key priorities for future research and have described evidence that beetles are important components of ecosystem and maintaining the health of the forest ecosystem as preys, pollinators, decomposers and predators and pests. This review has attempted to assemble all available information on the taxonomy, status, distribution, species diversity and bioecology of coleopteran fauna in Shivalik Hill areas of India. Several entomologists reported the number of various species of beetles, with their taxonomical characters, bioecology, distribution, species diversity, seasonal abundance and pest status that are found in their specific region. This helps us in understanding their importance at each tropic level in forest ecosystem. The scientists successfully verified the role of beetles as potential preys, bio indicators pollinators, predators and decomposers in various ecosystem of the world. One of the major roles of this fauna is acting as prey, decomposers, pollinators, predators and pests. Some of them are carrion feeders either vertebrate or invertebrate carrion while other feeds on fruits, leaves, flowers, stem, bark and other plant parts. This study implied that data available on Coleoptera $\mathrm{n}$ fauna in Shivalik Hills region of India are very limited. The above information on coleopteran in Shivalik Hills region of Indian laid wide scope for researchers in long term studies. Their role in forest ecosystem dynamics, functioning and as preys, pollinators, predators, decomposer and pest population is among the important aspects to be considered both biologically and ecologically due to current challenges of changing climatic conditions. Shivalik act as the transient zone between the Himalays and Tarai plains, several Himalayan elements present in this landscape. The study will also be helpful for the entomologists, conservationist, students, naturalist, planners, forest officials, policy makers and researchers working on different aspects of Coleoptera fauna. The observations recorded in the future study may prove valuable as a reference for assessing the changes due to the current changing environmental conditions in the locality, in future.

\section{CONCLUSION}

In this review, it is showed that the importance of beetles as preys, pollinators, decomposer, predators and pests for a diverse range of forest ecosystem in the region. The research directions outlined will help develop consolidate information on bioecology, taxonomy distribution, species diversity, seasonal abundance and pests status in current changing climatic condition. 


\section{ACKNOWLEDGEMENTS}

The author is thankful to Director, Zoological Survey of India and Officer-In-Charge, Northern Regional Centre, Zoological Survey of India, Dehradun for providing necessary facilities, suggestion and constant encouragement, time to time.

\section{REFERENCES}

Adis, J., Didham, R. K., \& Stork, N. E. (1997). Canopy Arthropods: Chapman \& Hall. pp. 567.

Agrawal, D., Farooquee, N., Samal, P., Sharma, S., \& Palni, L. (2002). Siwalik development strategy I. Action plan. GB Pant Institute of Himalayan Environment and Development, Almora, India.

Ahmad, P. (2000). New record of coccinellids from Uttar Pradesh II. Journal of Advanced Zoology, 21(1), 43-47.

Ahmad, P., \& Moina, K. (2019). Distribution and biodiversity indices of predaceous Coccinellidae (Coleoptera ) of Uttarakhand, North India. Biodiversity Journal, 10(3), 177-184.

Andrews, E. A. (1935). The Fauna of British India, including Ceylon and Burma: Coleoptera , Carabidae. Vol. II. Taylor and Francis Ltd., London, pp. 323

Andrews, F. (1929). The effect of temperature on flowers. Plant Physiology, 4(2), 281.

Arrow, G. (1949). The Fauna of India Including Pakistan, Ceylon, Burma and Malaya. Vol-4, Taylor and Francis, London.

Arrow, G. J. (1910). The fauna of British India, including Ceylon and Burma. I. Coleoptera : Scarabaeidae: Centoniinae and Dyanstinae. Taylor and Francis Ltd., London, pp. 322.

Arrow, G. J. (1925). The fauna of British India, including Ceylon and Burma. III. Coleoptera : Clavicornia: Erotylidae, Languriidae and Endomychidae. Taylor and Francis Ltd., London, pp. 416.

Arrow, G. J. (1931). The fauna of British India, including Ceylon and Burma IV. Coleoptera : Scarabaeidae: Coprinae. Taylor and Francis Ltd., London, pp. 428

Arrow, G. J. (1943). Systematic notes on the melolonthine beetles belonging to the genus Lepidiota and some related genera. Annual Magazine of Natural. History, 11(1), 773-785.

Arya, M. K., Joshi, P. C., \& Agarwal, A. (2014). Species diversity and fluctuation in population density of Coleoptera $\mathrm{n}$ insects of Shyampur forest range in the Shivalik foot hills, Haridwar, India. Journal of Environment and Bio-Sciences, 28(1), 85-91.

Arya, M. K., \& Tamta, P. (2016). Study on distribution and diversity of beetles (Insecta: Coleoptera ) in different elevational zones of Binsar Wildlife Sanctuary, Almora, Uttarakhand. India Journal of Entomology and Zoological Studies, 4, 311-316.
Banerjee, M. (2014). Diversity and composition of beetles (Order: Coleoptera ) of Durgapur, West Bengal, India. Psyche: A Journal of Entomology 2014(9),1-6

Beeson, C. F. C. (1941). The Ecology and Control of the Forest Insects of India and the Neighbouring countries. First reprint ed., Forest Research Institute \& Colleges, Dehra dun, $767 \mathrm{pp}$.

Bhardwaj, A., Srivastav, A., Pandav, B., Singh, P., Adhikari, B., Uniyal, V., Das, A. (2017). Ecological Assessment of Siswan Reserve, Punjab. Wildlife Institute of India, Dehradun, 1-39.

Bhardwaj, M., Bhargav, V. K., \& Uniyal, V. (2008). Occurrence of tiger beetles (Cicindelidae: Coleoptera ) in Chilla Wildlife Sanctuary, Rajaji National Park, Uttarakhand. Indian Forester, 134(12), 1636-1645.

Bhargav, V., \& Uniyal, V. (2008). Communal roosting of tiger beetles (Cicindelidae: Coleoptera ) in the Shivalik hills, Himachal Pradesh, India. Cicindela, 40(1-2), $1-12$.

Bhargav, V., Uniyal, V., \& Sivakumar, K. (2009). Distinctive patterns in habitat association and distribution of tiger beetles in the Shivalik landscape of North Western India. Journal of Insect Conservation, 13(5), 459-473.

Bind, R. (1995). Records of aphid-natural enemies complex of Uttar Pradesh. 1. The aphids. Indian Journal of Agricultural Research, 29(4), 215-218.

Browne, F. G. (1968). Pests and diseases of forest plantation trees: an annotated list of the principal species occurring in the British Commonwealth. Oxford, UK, Clarendon Press.

Cameron, M. (1930). The Fauna of British India. Vol-I, Taylor and Francis, London.

Cameron, M. (1939). The Fauna of British India, including Ceylon and Burma. Coleoptera, Staphylinidae, 411691.

Chakraborty,S. (2010). Insecta: Coleoptera: Coccinellidae. Fauna of Uttarakhand. Part 2. Insects, 283-301.

Chakraborty, S. K., Khan, H., Islam, S., \& Yousuf, B. A. (2010). Body Donation and its Significance in Anatomy Learning in Bangladesh A Review. Bangladesh Journal of Anatomy, 8(2), 85-88.

Champion, H., \& Seth, S. (1968). A revised survey of the forest types of India. Government of India Publications, 1(1), 297-299.

Chandra, K., Gupta, D., Gopi, K., Tripathy, B., \& Kumar, V. (2018). Faunal Diversity of Indian Himalaya. 1872. Published by the Director, Zoological Survey of India, Kolkata.

Chandra, K., Gupta, D., Uniyal, V., Bharadwaj, M., \& Sanyal, A. K. (2012). Studies on scarabaeid beetles (Coleoptera ) of Govind wildlife sanctuary, Garhwal, Uttarakhand, India. Paper presented at the Biological Forum-an International Journal. 
Chandra, K. S., \& Ramesh, G. (2013). The fourthgeneration Calcium channel blocker: cilnidipine. Indian Heart Journal, 65(6), 691-695.

Chatterjee, P., \& Thapa, R. (1970). Short note on Sal heartwood borer, Hoplocerambyx spinicornis Newn.(Cerambycidae) epidemic in the Thano Sal forests, Dehra Dun division. Indian Forester, 96(9), 697-698.

Chatterjee, S., \& Biswas, S. (2010). Insecta: Coleoptera : Scarabaeidae: Cetoniinae, Dynastinae, Rutelinae. Fauna of Uttarakhand, State, fauna Series, 18(2), 311321.

Dhaliwal, G., Jindal, V., \& Dhawan, A. (2010). Insect pest problems and crop losses: changing trends. Indian Journal of Ecology, 37(1), 1-7.

Editor-Director (1995). Faunal diversity of Rajaji National Park. Published by the Director, Zoological Survey of India. Kolkata.

Editor-Director. (2003). Fauna of Asan Wetland. Published by the Director, Zoological Survey of India. Kolkata.

Editor-Director. (2007). Faunal Diversity Western Doon Shiwalilks. Published by the Director, Zoological Survey of India. Kolkata. 1-141.

Editor-Director. (2008). Fauna of Corbett Tiger Reserve, Conservation Area Series. Published by the Director, 2001. Zoological Survey of India. Kolkata.1-230.

Editor-Director. (2010). Fauna of Uttarakhand, State Fauna Series. Published by the Director, Zoological Survey of India. Kolkata. 1-178.

FAO. (2010). Global Forest Resources Assessment 2010. Main Report. Food and Agriculture Organization of the United Nations.

Fowler, W. W. (1912). The fauna of British India, including Ceylon and Burma. Coleoptera : Cicindelidae, Rhysodidae, Paussidae. Taylor and Francis Ltd., London, 529 pp.

Gahan, C. (1906). The fauna of British India, including Ceylon and Burma. Coleoptera : Cerambycidae. Taylor and Francis Ltd., London, 329 pp.

Jerath, N., \& Chadha, J. (2006). Biodiversity in the Shivalik ecosystem of Punjab: Bishen Singh Mahendra Pal Singh.

Johnsingh, A., Ramesh, K., Qureshi, Q., David, A., Goyal, S. P., Rawat, G. S., Prasad, S. (2004). Conservation status of tiger and associated species in the Terai Arc Landscape, India: Wildlife Institute of India Dehradun.

Joshi, P. C., \& Sharma, P. K. (2008). First records of coccinellid beetles (Coccinellidae) from the Haridwar,(Uttarakhand), India. Tropical Natural History, 8(2), 157-167.

Kazmi, S. I., \& Ramamurthy, V. (2004). Coleoptera (Insecta) Fauna from the Indian Thar Desert, Rajasthan. Zoos' Print Journal, 19(4), 1447-1448.
Keffer, C. A., Mooers, C. A., Cotton, E. C., Quereau, F. C., Price, J. N., Voorhees, J. F., Barnes, S. E. (1908). Tick eradication: The life-history and habits of the North American fever tick with special reference to eradication (Vol. 79): University of Tennessee, Agricultural Experiment Station.

Kulkarni, N., \& Joshi, K. (1998). Insect pestes of forest tree seeds: their economic impact and control measures. Journal of Tropical Forest Science, 438-455.

Lal, J. (1989). India's Forests: Myth and Reality . Dehra Dun, India: Natraj Publishers.

Lefroy, H. M., \& Howlett, F. (1909). Indian Insect Life, Thacker, Spink \& Co., Calcutta: 786 pp.

Mahendiran, G., \& Ramamurthy, V. (2013). A checklist of the genus Blosyrus Schoenherr (Coleoptera : Curculionidae: Entiminae) of the world. Journal of Threatened Taxa, 5(12), 4682-4686.

Mani, M. (1968). Ecology and biogeography of high altitude: Junk. Series Entomologica.445 pp.

Marshall, G. A. (1916). The fauna of British India, including Ceylon and Burma. Coleoptera. Rhynchophora:-Curculionidae. The fauna of British India, including Ceylon and Burma. Coleoptera. Rhynchophor, Curculionidae., 116-117.

Maulik, S. (1919). The Fauna of British India, Including Ceylon and Burma. Coleoptera : ChrysomelidaeVol.II. Taylor anf Francis Ltd., London, 439 pp.

Maulik, S. (1926). The Fauna of British India, Including Ceylon and Burma. Coleoptera : Chrysomelidae, Vol. II. Taylor and Francis Ltd., London, 442 pp.

Maulik, S. (1936). The Fauna of British Indian, Including Ceylon and Burma. Coleoptera : Chrysomelidae, Vol. IV. Taylor and Francis Ltd., London, 648 pp.

Mishra, A. K., \& Yousuf, M. (2019). Notes on coccinellid beetles (Coleoptera : Coccinellidae) from forest ecosystem of Uttarakhand, India. Journal of Biological Control, 33(1), 1-6.

Mukhopadhyay, P., \& Ghosh, S. (2010). Insecta: Coleopter : Adephaga Famlly Gyrinidae and Dytiscidae. Fauna of Uttarakhand (Part-2), 269.

Mukhopadhyay, P., Rajesh, M., Pan, H., Patel, V., Mukhopadhyay, B., Bátkai, S., Pacher, P. (2010). Cannabinoid-2 receptor limits inflammation, oxidative/nitrosative stress, and cell death in nephropathy. Free Radical Biology and Medicine, 48(3), 457-467.

Nair, K. S. (2007). Tropical Forest Insect Pests: Ecology, Impact, and Management: Cambridge University Press.

Omkar, \& Pervez, A. (1999). New record of coccinellids from Uttar Pradesh. I. Journal of Advanced Zoology, 20(2), 106-112. 
Omkar, \& Pervez, A. (2002). New record of coccinellids from Uttar Pradesh III. Journal of Advanced Zoology, 23(1), 63-65.

Pajni, H., \& Bedi, S. (1973). Preliminary survey of the Cicindelid fauna of Chandigarh, Punjab, India. Cicindela, 5(3), 41-54.

Pajni, H., \& Singal, S. K. (1974). Corigetus chandigarhensis sp. nov., a new Curculioned from Chandigarh (Coleoptera: Curculionedae: Otierhynchinae: Ptochini: Cyphicerina. Zoological Journal of the Linnean Society, 55(1), 61-64.

Pajni, H., \& Singh, J. (1982). report on the family Coccinellidae of Chandigarh and its surrounding areas (Coleoptera). Research bulletin-Panjab Univeristy. New series: Science.

Pajni, H. R. (1990). Fauna of India and adjacent countries. Coleoptera : Curculionidae, Subfamily Eremninae Tribe Cyphicerini. Zoological Survey of India. The Technical and General Press, Calcutta, India, 490-492 p.

Pathania, M. (2015). Diversity and population dynamics of phytophagous scarabaeid beetles (Coleoptera: Scarabaeidae) in different landscapes of Himachal Pradesh, India. Arthropods, 4(2), 46.

Poorani, J. (2002). An annotated checklist of the Coccinellidae (Coleoptera )(excluding Epilachninae) of the Indian subregion. Oriental Insects, 36(1), 307-383.

Ramakrishna, A. J. (2007). Faunal resources in India. Zoological Survey of India, Kolkata, 1-428.

Ranjeet, S., Goraya, G., Charan, S., Shalindra, K., \& Surinder, K. (2001). Mortality of Chir pine trees by insect borers in Morni Hills, Haryana-a case study. Indian Forester, 127(11), 1279-1286.

Rawat, G., \& Mukherjee, S. (2005). Biodiversity of the foothills of the Himalaya. Paper presented at the Proceedings of the Workshop on conservation of Biodiversity in India status, challenges and eflorts,(Rawat, JK, Srivastava, SK, Biswas, S., Vasistha, HB Eds). Indian Council of Forestry Research and Education, Dehradun.

Roonwal, M. (1952). The natural establishment and dispersal of an imported insect in India-the lantana bug, Teleonemia scrupulosa (Hemiptera: Tingidae) with a description of its egg, nymph and adult. Journal of Zoological Society of India, 4, 1-16.

Roonwal, M. (1978). Biology, ecology and control of the sal heartwood borer, Hoplocerambyx spinicornis: A review of recent work. Indian Journal of Forestry. (1), 21-34,

Sambaraju, K., DesRochers, P., Rioux, D., Boulanger, Y., Kulkarni, N., Verma, R. K., Hébert, C. (2016). Forest ecosystem health and biotic disturbances: perspectives on indicators and management approaches. Larocque GR. CRC Press, Management Handbook, 459-515.
Singh, A. P., Shagun, M., Kritish, D., Uniyal, V., \& Bhardwaj, A. (2018). An assessment of coleopteran fauna of the forest of Siswan, Punjab. Indian Forester, 144(11), 1107-1113.

Singh, P. (1988). First report on Scarabaeid (Coleoptera ) fauna of Sahaspur, Uttarakhand. Journal of Entomology and Zoology Studies, 5(6), 17-22.

Stebbing, E. P. (1899). Injurious insects of Indian forests. Calcutta: Supt. Govt. Printing Press.

Stork, N. E. (1988). Insect diversity: facts, fiction and speculation. Biological Journal of the Linnean Society, 35(4), 321-337.

Tewari, D. N. (1992). Tropical forestry in India: International Book Distributors.

Thakare, V., \& Zade, V. (2012). Diversity of beetles (Insecta: Coleoptera ) from the vicinity of SemadohMakhala road, Sipnarange, Melghat Tiger Reserve,(MS) India. Bioscience Discovery, 3(1), 112115.

Thapa, R., \& Pratap, S. (1990). Insect borers killing firescorched chir pine trees and their control in Nahan Forest Division, Himachal Pradesh. Indian Forester, 116(5), 375-380.

Trigunayat, K., \& Sharma, J. (2017). Diversity and ecology of Coleoptera in India: A review. Journal of Entomology and Zoology Studies, 5(2), 1422-1429.

Uniyal, V., \& Bhargav, V. (2007). Tiger Beetles: A Field Study in The Shivaliks of Himachal Pradesh: Wildlife Institute of India.

Uniyal, V., Sivakumar, K., Padmawathe, R., Kittur, S., Bhargav, V., Bhardwaj, M., \& Dobhal, R. (2007). Ecological study of tiger beetles (Cicindellidae) as indicator for biodiversity monitoring in the Shivalik landscapes. DST Project Completion report. Wildlife Institute of India (WII), Dehradun.

Vazirani, T. (1977). Notes on a collection of Dytiscidae (Coleoptera ) from Maharashtra, with description of a new species. Records of Zoological Survey of India, 73, 123-133.

Vazirani, T. G. (1984). The fauna of India: Coleoptera . Family Gyrinidae and Family Haliplidae. Zoological Survey of India, 1-101.

Verma, J. P., Jaiswal, D. K., Singh, S., Kumar, A., Prakash, S., \& Curá, J. A. (2017). Consequence of phosphate solubilising microbes in sustainable agriculture as efficient microbial consortium: a review. Climate Change and Environmental Sustainability, 5(1), 1-19.

Wadia, D. (1975). 1975: Geology of India. New Delhi: Tata McGraw-Hill, 50-50. 